\author{
Kamila Szwaczkiewicz \\ dr inż. \\ Politechnika Gdańska, \\ Wydział Inżynierii Lądowej i Środowiska, \\ Katedra Transportu Szynowego i Mostów \\ kamszwac@pg.gda.pl
}

\title{
Optimizing the process of railway geometrical layout designing with multi-criteria assessment method
}

\begin{abstract}
The paper presents the main assumptions of the Multi-criteria assessment method used in process of upgrading the railway geometrical layout. The advantages of metaheuristic search were described. The criteria influencing the investment were defined. The fitness function used in the analysis was described. The example of using the optimization algorithm with the help of self developed computer software was described.
\end{abstract}

Keywords: geometrical layout, upgrading, multi-criteria optimization, GA, LCC.

\section{Introduction}

Numerous ongoing upgrading investments in Poland are performed to increase the velocity and - from the passenger point of view - to shorten the time of travel. Extended traveling resulting from the state of infrastructure might be a reason of decreasing interest in railway transport. Polish Railway Infrastructure Manager main goals should therefore be the maintenance and improvement of technical and quality conditions. Thus, the renewal or upgrading of the improperly maintained section of line should be considered.

In this situation, to achieve this aim the geometrical layout is changed and structural elements of the track are replaced.

Still, the main goal in the actual feasibility studies is to perform the investment with the minimization of the costs (the cheapest variants). Nevertheless, concentrating only on one criteria without taking into account the others may lead to the reduction of the line upgrading possibilities in future. Factors affecting the degree of complexity of the upgrading process are the significant number of criteria affecting the quality of the variant and the lack of dedicated tools for multi-criteria analysis, adapted to the needs of the layout upgrading projects [25].

Computer Aided Design (CAD) programs provide significant help in graphic designing. However, such a software does not optimize geometry. The designer determines geometrical parameters basing on gained experience, calculations and law rules. Data is then implemented into advanced graphic programs which draw up designed layout. Therefore, there is still a need to create a tool that would enable efficient generation of design variants and their optimization and assessment.

Single optimization techniques are mainly uses when one criteria is influencing the fitness function. This kind of methods are adequate only if there are no other factors affecting the problem or when one of the criteria is dominant. Therefore, analyzed problem requires more than optimizing one parameter. Due to the features of the project and the complexity of the process of upgrading railway lines, multi-criteria analysis methods are necessary. The key issue is to chose an adequate method of optimization and to build proper fitness function that will take into account main criteria of the project. Each parameter should be appropriately considered minimized or maximized. 


\section{The optimization method}

Metaheuristic search combines two actions: exploration and exploitation. During the process of exploration the search for areas where optimum (promising) solution might be found is analyzed. On the other hand, the exploitation process is used to test found limited region with the intesification of the search in the neighborhood of promising solution. The key aspect is to balans this two operations and to find promising solution and avoid getting stuck in the local optima. Therefore, this kind of optimization algorithm is developed to improve existing solution. This is exactly what seems to be needed to solve this engineering problem.

The number of heuristic algorithms has been increasing over the years and to choose one of them the analize of the literature has been performed. At first, it was decided to use the metaheuristic search from a variety of availiable methods. Taking into account studies in the engineering field the algortihms with multiple candidates were promising i.e. population based methods:

- genetic algorithms [10,19,20],

- particle swarm optimization [13, 27],

- ant colony optimization[6,17],

- artificial bee colony.

Evolutionary algorithms became a matter of interested in the late 50s of the twentieth century $[2,4,9]$. However, the development of evolutionary calculations has begun in the $70 \mathrm{~s}$ $[10,20]$. The studies were describing the basics of genetic algorithms. From that moment, a general interest in these issue has been noticed [15].Their popularity can be observed in various fields engineering. The implementation of GA (genetic algorithms) to the engineering problems has been presented in works[5,14]. The universality of these methods causes them to be used also in the railway transport [16].

The examlpe of the implementation of the GA into railway geometical problems has been described in the doctoral dissertation of K.Palikowska [16]. The author developed the method of designig the geometical layout based on modeling the curvature. The problem required using computer support and GA were found to be usefull. Adopted optimization method has proved to be extremely effective - mainly due to the possibility of genetic modifications. Presented solutions, mostly from the point of view of the efficiency and possibilities of implementation of algorithms in selected programming language, has been and inspiration to develop a new method presented in this paper.

Genetic algorithms are built on the basis of evolutionary mechanisms known from nature. These processes are designed to create a population of various individuals more or less adapted to survive. During the process of optimization there is a competition between the members of the population. However, the individuals that perform better are more likely to get to the next population. Also, whats characteristic in the GA the stadium of genetic operators gives the possibility to find a better area of search and avoid stucking into the local optima. Nevertheless, before using the algoritms to the mentioned problem was analyzed in the fields of:

- rules of operation,

- principles of creating new population,

- number of population,

- number of individuals (chromosomes),

- chromosomes form (gens),

- fitness function form,

- fitness function criteria,

- technical standards of designig (acceptable parameters). 


\section{The main criteria selection}

The preliminary assumptions were made to plan the operation of optimization. First, the criteria that would be included in the analysis were determined. The role of them in the investment process was assessed. The parameters that should be taken into account in the upgrading of railway geometrical layout are i.e.[25]:

- the cost of investment,

- the cost of maintenance,

- enviromental aspects,

- the health and life of people,

- the scope of earthworks

- noise and vibration,

- monuments and archaeological sites,

- the location of the engineering structures and existing infrastructure,

- the velocity on the lines nearby,

- ground and water conditions,

- earth conditions,

- the type of line.

The main three criteria were selected for the further analisys.

- the cost of investment and maintenance of rails - based on the LCC method (Life Cycle Cost [3]),

- the scope of earthworks and location of existing infrastructure,

- the maximum velocity possible to achieve on the designed arc.

Selected criteria require both minimization (cost and earthwork criterion) and maximization (speed criterion).

\section{The fitness function form}

The choice of the appropriate fitness function form (in genetic algorithms referred to as FF) is crucial in the process of optimization. Nevertheless, the base form of it has been changed during analysis of generated solutions. Such procedure is imposed by the need of finding the form of function that will enable to find the most promising solutions (from the main criteria point of view).

The form of the fitness function has been described by the following equation (1):

$$
F F=\frac{1}{f_{L C C} \cdot L C C_{\text {rail }}+f_{E} \cdot|E|-f_{V_{\max }} \cdot V_{\max }^{2}}
$$

where:

- $f_{L C C}$ - weight of LCC,

- $L C C_{\text {rail }}$ - the life cycle cost of rails,

- $f_{E}$ - weight of the earthworks value,

- $E$ - the scope of earthworks,

- $f_{V_{\max }}$ - weight of the velocity,

- $V_{\max }$ - maximum velocity possible to achieve on the designed arc.

The final FF form can have many locally optimal solutions. The FF and the weights of the selected criteria are dimensionless. The fitness function does not take a negative value, which is ensured by the constraining conditions. Such solutions are excluded due to appropriately analyzed factors and maximum velocity. In the described method the value of 
the fitness function is maximized. The life cycle cost of the rail as well as the scope of earthworks should be minimalized, so the corresponding criteria are in the denominator of the equation. Maximizing velocity criterion was obtained by assigning a negative value (corresponding to the weight).

First criteria taken to the account is the life cycle cost (LCC) of rails. The LCC is calculated as the total cost of the object performance over time and includes the acquisition, operating, maintenance, and disposal costs [3]. Thus, in the considered problem the costs would include investment, operating costs and those related to the maintenance. The investment cost in this case is the acquisition of rail. The assembly, pre-grinding and welding of rails have been calculated as the operating costs. The maintenance costs include the lateral and vertical wear of the rail head. The degradation models were created on the base of INNOTRACK project guidelines[11,12]. Thus, the maintenance cost has been defined as the cost of preventive grinding and replacement of rail section [26]. The LCC model has been created due to the Polish Regulations $[7,8,18]$ which determine the use of rail steel grades. Therefore, the choice of steel grades depends on the radius of the arc. Thus, for the arcs with the radius under $800 \mathrm{~m}$ the R350HT steel rails were assumed. For the radius over and equal to $800 \mathrm{~m}$ the R260 was considered [26].

The second criteria is the scope of earthworks and it has been calculated on the basis of self developed algorithms. The volume value depends on the hight of fill (depth of the cut), longitudinal and transverse terrain slope. The accuracy of the calculations depends on the assumed calculation step. A detailed description of the method of determining the scope of earthworks was presented in works [23,24].

Finally, the last but very important criteria is the maximum velocity that is possible to achieve in the design layout. The value is being calculated according to the Polish law rules $[7,8,18]$. It takes into account values of permissible geometric and kinematic parameters. To increase the importance of this criteria the velocity value has been raised to the square.

\section{Definition of the chromosome and the algoritm tuning}

The chromosome form was determined by the geometrical parameters of the arc with transition curves. Therefore, the limits of the gens were defined according to the Polish rules[7,8]. None of chromosomes was incorrect in the meaning of permissible kinematic and geometrical parameters. After determining the constrains, the form of the individuals was defined as:

- the length of transition curve,

- the radius of the arc.

Both genes were described by the unit of meter. The analysis of the weight of each criteria has been performed during the process of tuning the algorithm. The values were defined basing on the generated solutions. The process of tuning was continued till the geometrical layouts were promising and better than once made with basic calculation methods. After this stage, the incorrect or not satisfying solutions would be "punished" or eliminated from the population.

At the tuning stage of the algorithm, it was necessary to include non-formal knowledge of the topic. Tuning the algorithm should include the individual characteristics of the generated solutions and the possibility of their implementation.

The detailed description of the individuals generating (geometrical layots) and the genetic algorithm form used in developed method has been presented in the paper [22]. 


\section{The method assumptios}

It was assumed that before the optimisation process the following parameters of the existing geometrical are known:

- the length of transition curves,

- the radius of the arc,

- the angle of the turn,

- the kinematic parameters of the line,

- the longitudinal and transverse slope of the terrain.

Generated designed layout would be defined with the following parameters:

- the length of transition curves,

- the radius of the arc,

- the angle of the turn (does not change in realation to the existing layout),

- the kinematic parameters of the line,

- the scope od earthworks,

- the value of the cant,

- the maximum velocity possible to achieve on the layout.

The designed layout is performed in relation to the existing layout. The method of designing is based on the Polish rules [7,8] and takes into account the permissible values of both kinematic and geometrical parameters. The transition curves are designed in the form of cubic parabola. The length of both transition curves is the same.

\section{The muticriteria method implementation}

The genetic algorithm bases on the hudge generation of chromosomes i.e. 1000 of generated individuals in one population. The number of population is also over 1000. That requires the computer support. Therefore, the multicriteria method was implemented in C\# programming language to the self developed computer program called MUGO.

The computer program consists of two parts. First one was created to give a detailed information of the relation between the existing and designed layout (track axis). It was performed for different types of geometrical layouts such as:

- the arc without transition curves,

- the compound arc,

- the parabolic arc,

- the arc with transition curves [1].

The second part of the program is an optimisation of the geometrical layout. The multicriteria method basing on the GA was implemented there.

\section{The example of the calculation}

The existing geometrical layout is defined by the following values:

- the length of transition curves $\mathrm{L}=70 \mathrm{~m}$,

- the radius of the arc $\mathrm{R}=450 \mathrm{~m}$,

- the angle of the turn $\omega=30^{\circ}$,

- the load of freight trains $\mathrm{T}=17 \mathrm{MGT}$ per year,

- the depth of the cut $\mathrm{H}=2 \mathrm{~m}$,

- the longitudinal slope of the terrain $\mathrm{i}=-8 \%$.

It was assumed that the value of designed velocity cannot be less than $120 \mathrm{kph}$ and the average velocity for the freight trains should be $60 \mathrm{kph}$.

The basic calculation (without optimisation) defines the parameters of newly designed layout $\mathrm{ARC}_{0}$ as following:

- the length of transition curves $\mathrm{L}_{\mathrm{M}}=143 \mathrm{~m}$, 
- the radius of the arc $\mathrm{R}_{\mathrm{M}}=750 \mathrm{~m}$,

- the angle of the turn $\omega=30^{\circ}$,

- the maximum track axis offset $\mathrm{w}_{\max }=11,26 \mathrm{~m}$,

- the volume of earthworks $E=3491 \mathrm{~m}^{3}$.

The parameters of existing arc has been then implemented into the optimisation module. The generation of 3000 promissing solutions has been performed. Three selected layouts have been presented in the table 1 .

Tab.1. Parameters of designed arcs

\begin{tabular}{|c|c|c|c|c|c|}
\hline & $\mathrm{L}_{\mathrm{M}}[\mathrm{m}]$ & $\mathrm{R}_{\mathrm{M}}[\mathrm{m}]$ & $\mathrm{W}_{\max }[\mathrm{m}]$ & $\mathrm{V}_{\max }[\mathrm{kph}]$ & $\mathrm{E}\left[\mathrm{m}^{3}\right]$ \\
\hline $\mathbf{A R C}_{\mathbf{1}}$ & $\mathbf{1 2 0}$ & $\mathbf{7 5 5}$ & $\mathbf{1 1 , 1 0}$ & $\mathbf{1 2 0}$ & $\mathbf{3 4 0 4}$ \\
\hline $\mathrm{ARC}_{2}$ & 118 & 763 & 11,35 & 120 & 3423 \\
\hline $\mathbf{A R C}_{\mathbf{3}}$ & $\mathbf{1 0 3}$ & $\mathbf{8 2 1}$ & $\mathbf{1 3 , 1 7}$ & $\mathbf{1 2 0}$ & $\mathbf{3 5 2 7}$ \\
\hline$\ldots$ & $\ldots$ & $\ldots$ & $\ldots$ & $\ldots$ & $\ldots$ \\
\hline $\mathrm{ARC}_{0}$ & 143 & 750 & 11,26 & 120 & 3491 \\
\hline
\end{tabular}

All presented arcs created with optimization method are better in the meaning of adopted assumtions. Therefore, the $\mathrm{ARC}_{3}$ is the solution with the radius over $800 \mathrm{~m}$. So there is no need of using the rail $\mathrm{R} 350 \mathrm{HT}$ what means less costs of the investment. However, $\mathrm{ARC}_{1}$ and $\mathrm{ARC}_{2}$ volume of eartworks is less than for the $\mathrm{ARC}_{0}$ (without optimization). Also, $\mathrm{ARC}_{1}$ maximum axis offset is less than for the $\mathrm{ARC}_{0}$.

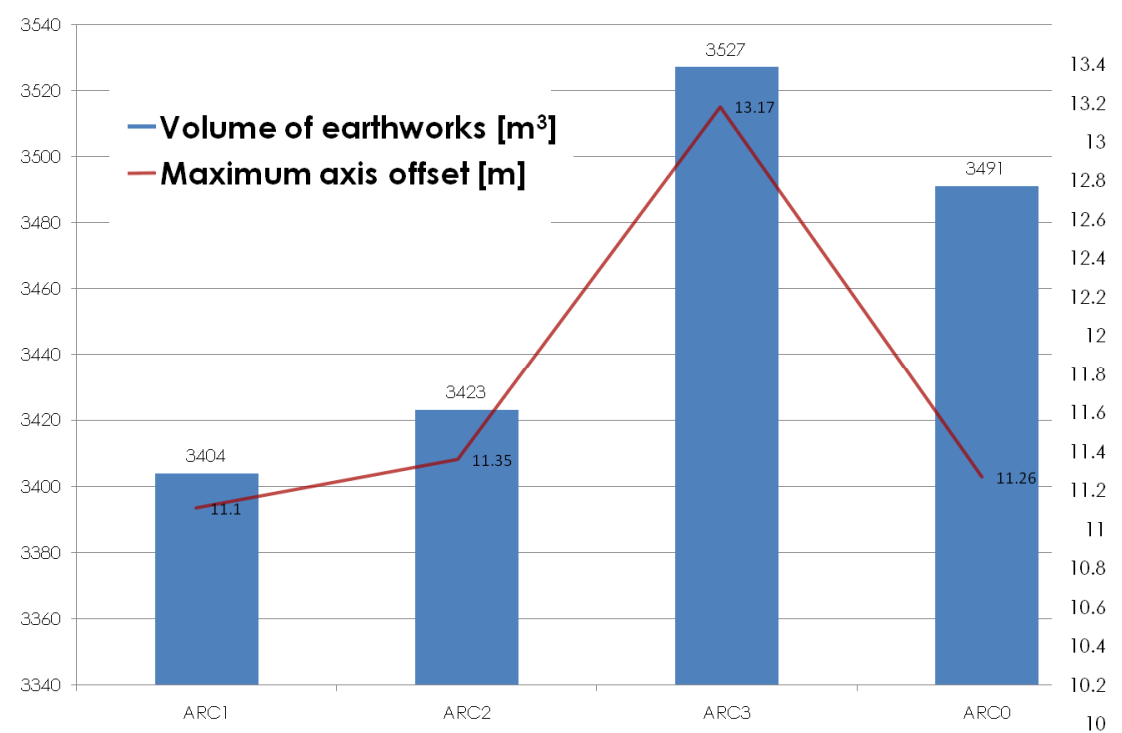

1. Presentation of designed layouts

\section{Conclusions}

The main reason for using metaheuristic search is to find and generate promising designing solutions instead of locally optimal solutions. The advantage of this approach is cost reduction, time saving and increased efficiency. The length of calculations and the effectiveness of this method depends on the population size, number of repetitions, algorithm tuning, case parameters, hardware capabilities. The developed method helps to find the correct solutions with the analyze and optimisation of the adopted criteria. Generated and analised solutions may provide an aid at the stage of feasibility study or the analysis of the selected design options i.e. by identifying the offsets of track axis. 
Further work may involve the development of earthworks solutions for example using the geosyntetic materials for fills and cuts. There is also possible to expand the algorithms to the cases of compound curves and the implementation of these cases into optimization algorithms (with new values of weights and algorithm tuning). In the further phase, it is also possible to analyze other types of metaheuristics search such as particle swarm optimization (PSO). Another direction of study development may also be the use of different types of transition curves, such as clotoids.

\section{Source materials}

[1] Bałuch H., Bałuch M., Układy geometryczne toru i ich deformacje. KOW, Warszawa 2010.

[2] Box G.E., Evolutionary operation: A method for increasing industrial productivity, Appl. Statistics, VI(2), 1957.

[3] Borghagen L., Brinkhagen L.: LCC Procurement at the Swedish State Railways, Proceedings Annual Reliability and Maintainability Symposium, IEEE, 1984.

[4] Bremerman H.J., Optimization through evolution and recombination, Self Organizing Systems, 1962.

[5] Brzychczy E., Tradycyjne metody optymalizacji a nowoczesna heurystyka w wybranych zagadnieniach modelowania robót górniczych w kopalniach węgla kamiennego, Gospodarka surowcami mineralnymi, 24, 2008.

[6] Dorigo M., Birattari M., Stutzle T., Ant colony optimization, Computational Intelligence Magazine, IEEE, 1(4), 2006.

[7] Dz. U. nr 151 poz. 987 z dnia 10 września 1998 roku: Rozporządzenie Ministra Transportu i Gospodarki Morskiej w sprawie warunków technicznych jakim powinny odpowiadać budowle kolejowe i ich usytuowanie.

[8] Dz. U. 2014 poz. 867 z dnia 5 czerwca 2014 roku: Rozporządzenie Ministra Infrastruktury i Rozwoju zmieniające Rozporządzenie w sprawie warunków technicznych, jakim powinny odpowiadać budowle kolejowe i ich usytuowanie.

[9] Friedberg R.M., A learning machine: Part 1, IBM, 2(1), 1958.

[10] Holland J.H., Adaptation in Natural and Artificial Systems, University of Michigan Press, 1975.

[11] INNOTRACK Integrated Project (IP) Thematic Priority 6: Sustainable Development, Global Change and Ecosystems D4.1.4 Rail Degradation Algorithms, 2006.

[12] INNOTRACK Guideline, Definitive guidelines on the use of different rail grades, Deliverable report D4.1.5GL, 2006.

[13] Kennedy J., Eberhart R., Particle swarm optimization, Neural Networks, 1995.

[14] Kosmol J., Wilk P., Próba optymalizacji korpusu obrabiarki z zastosowaniem MES i algorytmu genetycznego

[15] Koza J.R., Genetic Programming, MIT Press, 1992.

[16] Palikowska K., Projektowanie układów geometrycznych toru kolejowego z zastosowaniem programowania ewolucyjnego, Rozprawa doktorska, Politechnika Gdańska, 2002.

[17] Parpinelli R., H. S. Lopes A.A.F., Data mining with an ant colony optimization algorithm, Evolutionary Computation, IEEE Transactions on, 6(4), 2002

[18] PKP Polskie Linie Kolejowe S.A.: Warunki techniczne utrzymania nawierzchni na liniach kolejowych Id-1, Warszawa 2005. 
[19] Rechenberg I., Evolutionsstrategie - Optimierung technischer Systeme nach Prinzipien der biologischen Evolution, Fommann-Holzboog, 1973.

[20] Schwefel H.P., Numerical Optimization of Computer Models, Birkhäuser Verlag, Basel, 1977.

[21] Szwaczkiewicz K., Kędra Z. Obliczanie przesunięć osi toru przy modernizacji układów geometrycznych. Zeszyty Naukowo-Techniczne Stowarzyszenia Inżynierów i Techników Komunikacji w Krakowie Nr 2(101), Kraków 2013

[22] Szwaczkiewicz K. Koncepcja zastosowania algorytmów genetycznych przy modernizacji układów geometrycznych. Zeszyty Naukowo-Techniczne SITK RP oddział w Krakowie Nr 3(99), Kraków 2012.

[23] Szwaczkiewicz K. Obliczanie robót ziemnych przy modernizacji linii kolejowych. Zeszyty Naukowo-Techniczne SITK RP oddział w Krakowie, Nr 3(102). Kraków 2013.

[24] Szwaczkiewicz K., Earthworks calculations due to reconstruction of railway geometrical layout. Projektowanie, budowa i utrzymanie infrastruktury w transporcie szynowym. SITK RP, Radom 2014.

[25] Szwaczkiewicz K., Szmagliński J. Propozycja wykorzystania praktyki kolejowej przy modernizacji torów tramwajowych. Logistyka, Nr 3. Poznań 2015.

[26] Szwaczkiewicz K., Modernizacja układów geometrycznych toru z wykorzystaniem metody oceny wielokryterialnej, Przegląd Komunikacyjny, (9), 2015.

[27] Venter G., Sobieszczanski-Sobieski J., Particle swarm optimization, AIAA Journal, 11(8), 2003. 